\title{
A COGNITIVE AND CROSS-CULTURAL STUDY ON BODY PART TERMS IN ENGLISH AND TURKISH COLOUR IDIOMS*
}

\author{
Gökçen Hastürkoğlu**
}

\begin{abstract}
This study aims to reveal and compare the embodied cognition of English and Turkish speakers through their use of body part terms in basic colour term idioms. More specifically, it addresses the distribution of the body part terms in Turkish and English basic colour term idioms and conceptual metonymies underlying these idioms, and it interprets the findings in terms of socio-cultural and socio-cognitive structures in the minds and linguistic practices of people of Turkish and English cultures. In order to achieve this aim, the idioms with Berlin and Kay's basic colour terms and body part terms are selected from the specialized dictionaries on idioms. After the collection of data, the cognitive analysis is conducted within the framework of Conceptual Metaphor Theory. The result demonstrates that although there are some conceptual metaphors and metonymies which tend to be universal as they are grounded in bodily experience, English and Turkish speakers' conceptualizations through the basic colour terms and body parts vary tremendously because of different socio-cultural and socio-cognitive backgrounds of these speech communities.
\end{abstract}

Key Words: body parts, colour idioms, conceptual metonymy, cultural cognition

\section{Introduction}

The concepts of conceptual metaphor and conceptual metonymy have been used frequently in recent years especially with the cognitivist approaches to language which use the notion of embodiment as the starting point in the studies conducted within the framework of disciplines such as cognitive sciences, linguistics, and cultural studies.

In Embodiment and Cognitive Science, Gibbs (2006, p. 9) outlined the 'embodiment premise' as follows:

People's subjective, felt experiences of their bodies in action provide part of the fundamental grounding for language and thought. Cognition is what occurs when the body engages the physical, cultural world and must be studied in terms of the dynamical interactions between people and the environment. Human language and thought emerge from recurring patterns

\footnotetext{
* This study is based on a part of the PhD Thesis of the researcher entitled "A Cognitive Study on the Comparison of Basic Colour Terms in Turkish and English Idioms".

** PhD at Atılım University, Department of Translation and Interpretation, Ankara, Turkey, e-mail: gokcen.hasturkoglu@atilim.edu.tr
} 
of embodied activity that constrain ongoing intelligent behaviour. We must not assume cognition to be purely internal, symbolic, computational, and disembodied, but seek out the gross and detailed ways that language and thought are inextricably shaped by embodied action.

As Gibbs suggests embodiment is related to the physical and biological body, also to the social body and the linguistic practices of people are directly affected by their experiences in the social world.

Lakoff and Johnson, in Metaphors We Live By, discussed the metaphorical structure of human mind and revealed the tendency of structuring abstract concepts in terms of more concrete concepts (1980, p. 109) in the process of meaning-making. Metaphors and metonymies were described as correspondences between conceptual domains which are source and target ones. The difference between conceptual metaphors and metonymies lies in the fact that in metaphor there are two separate domains while metonymy takes place within only one domain. Metonymy means referring one thing in order to refer to another which is related to it. One of the definitions provided that "Metonymy is a cognitive process in which one conceptual entity, the vehicle, provides mental access to another conceptual entity, the target, within the same idealized cognitive model" (Radden and Kövecses, 1999, p. 21). Metonymy emerges from three types of relationships: WHOLE FOR PART and PART FOR WHOLE and PART FOR PART (Barcelona, 2011; Kövecses and Radden, 1999).

In this study, as a kind of PART-WHOLE metonymy, body part relation is investigated in the idioms, more specifically basic colour term idioms, which are one of the most prominent representative aspect of culture. It is commonly believed that in terms of the center of thoughts, feelings and actions, different languages have different locus in the body. For instance, the heart is believed to be the central faculty of cognition including emotional and intellectual activities in Chinese (Yu, 2008, 2009), while liver is observed to be the center of both emotional and mental activities in Indonesian (Siahaan, 2008). Thus, in this article, idioms which are constructed around basic colour terms (white, black, red, green, blue, yellow, brown, pink, purple, orange, and grey) as Berlin and Kay (1969) put it, and collocated with body part terms are elaborated on in order to shed light on the similarities and variations of collocational realizations of colours and body parts in Turkish and English speaking communities by providing the socio-cultural motivation behind these conceptualizations. As the idioms are regarded as one of the most culture-representative linguistic elements, analyzing and comparing the idiomatic expressions constructed with the basic colour terms and body parts are thought to be an effective study for not only linguistic but also cultural and cognitive reasons. 


\section{Previous Research in the Field}

Body part terms have taken the attention of some scholars in recent years in Turkey. They have been investigating the body-part terms with different approaches especially from the perspective of cognitive linguistics. Among them, Öz (2011) analyzes the use of head and its subparts such as mouth, eye, ear, etc. to reveal the figurative language uses by adopting Conceptual Metaphor Theory. Aksan (2011) studies the mataphorical uses of head (baş) and foot (ayak) in Turkish with respect to the image schema of verticality. He concludes that head and foot are valued and conceptualized differently because of their positions in the body, as head is topmost and feet are the lowest. Ruhi \& Iş1k-Güler (2007) investigates the conceptualization of face (yüz) in Turkish and presents the use of this body part term in order to reflect emotions. Baş (2015) reveals the embodied cognition of Turkish speakers via the idiomatic use of body part terms in order to communicate their emotions and reveales how emotion is culturally conceptualized by Turkish speakers.

The number of cognitive studies on colour terms is fewer than those analyzing the body part terms in Turkish. For instance, Hastürkoğlu (2017) compares the cognitive motivations of basic colour terms in Turkish and English idioms in order to find out the distribution and frequency of basic colour term idioms, to specify and compare the conceptual metaphors/metonymies underlying them, their meta-domains and sub-domains, the positive, negative, or neutral qualities attributed to these idioms and interprets the findings in terms of socio-cultural and socio-cognitive structures in the minds and linguistic practices of people of Turkish and English cultures.

After reviewing the previous studies on body part terms and colours, the present study aims to investigate and compare the use of the basic colour terms collocated with the body part terms in Turkish and English idioms for revealing the conceptualizations and embodied cognition of Turkish and English speaking communities.

\section{Method}

The idioms analyzed in this study were collected from a large number of specialized dictionaries of idioms in English and Turkish. For the English data, Cambridge International Dictionary of Idioms, Thesaurus of Traditional English Metaphors, Oxford Dictionary of Idioms, Collins CoBuild Dictionary of Idioms, Metaphorically Speaking: A Dictionary of 3800 Picturesque Idiomatic Expressions, McGraw-Hill's Dictionary of American Idioms and Phrasal Verbs, Dictionary of Idioms and Their Origins were scanned. For the Turkish corpus, the colour term idioms with body parts in the Online Dictionary of Proverbs and Idioms of Turkish Language Association (TDK) and in a number of printed 
dictionaries on idioms which were compiled by Yörük and Yörük (1997) and Aksoy (1998) were gathered for this study.

The quantitative and descriptive data analysis was conducted after the preparation of the final list of the idioms of both languages. The results were illustrated through a table for each basic colour term in order to show the similarities and differences between the conceptualizations of English and Turkish speakers.

Furthermore, the cognitive analysis of the data focused mainly on identifying the main conceptual metonymy around which each idiom revolved within the framework of Conceptual Metaphor Theory and the findings were interpreted by taking into account different socio-cultural and socio-cognitive structures of Turkish and English speakers.

\section{Results and Discussion}

After the collection of the data, it can be put forward that Turkish is richer than English in terms of the number of the distribution of body part terms in basic colour term idioms. The results are demonstrated through the tables below for each basic colour term used in idioms with body parts and the discussions on the underlying conceptual metonymies follow each table.

Table 1. Distribution of Body Part Terms in Turkish and English White Colour Idioms

\begin{tabular}{|l|l|l|l|}
\hline Body Part Term in Turkish & Number & Body Part Term in English & Number \\
\hline Yüz (Face) & 6 & Liver & 1 \\
\hline Sakal (Beard) & 4 & Hand & 1 \\
\hline Saç (Hair) & 3 & & \\
\hline Göz (Eye) & 2 & & \\
\hline Saç (Hair) with Sakal (Beard) & 1 & & \\
\hline Saç (Hair) with Baş (Head) & 1 & & \\
\hline Topuk (Ankle) with Gerdan (Throat) & 1 & & \\
\hline Şakak (Temporal) & 1 & & \\
\hline Alın (Forehead) & 1 & & \\
\hline Alın (Forehead) with Yüz (Face) & 1 & & \\
\hline
\end{tabular}

In Turkish, there are 21 idioms with a body part term which are ak gözlü, ak sakaldan yok sakala gelmek, ak sakallı, ak topuk beyaz gerdan, ak yüzlü, alnı 
açık yüzü ak, alnının akıyla, gözünü ağartmak, saç ağartmak, saçı değirmende ă̆artmamak, saçı başı ăgarmak, saçına ak düşmek, şakakları ağarmak, sakalı değirmende ă̆artmak, sakalına ak düşmek, yüz akl, yüzü ak, yüzü kireç gibi ağarmak, (bir işte) saç sakal ă̆artmak, (bir işten) yüz (yüzünün) akıyla çıkmak, (birinin) yüzünü ağartmak demonstrating the fact that body part terms are frequently collocated with the colour white by Turkish speakers.

As illustrated in Table 1 yüz (face) is the major bodily center in Turkish mostly associated with moral concepts such as honesty, honour, and innocence as it is the fact in alnı açı yüzü ak and ak yüzlü in which the mapping between white and face has generated the general conceptual metonymy WHITE FACE STANDS FOR MORALITY, or in terms of the sub-concept, there is WHITE FACE STANDS FOR HONESTY conceptual metonymy. As it is also stated by Ruhi and Işı1k Güler, yüz (face) is closely related to "identity claims, socially valued attributes, evaluative judgments on moral values, and equity in sociality rights" (2007, p. 688) as in the Turkish examples. Furthermore, yüzü kireç gibi olmak signifies fear which proves the fact that face is an important external body part in the expression of emotions (Yu, 2002, p. 344). This idiom contains a metonymic relation between source and target domain generating WHITE LIVER STANDS FOR COWARDICE conceptual metonymy.

Sakal (beard) is the body part term with the highest frequency in Turkish. The white beard is associated with old age, as hair of human beings turns white when they become old. Sakal is used in Turkish together with hair and head again signifying old age, and also wisdom. What is more, şakak (temporal) which is white also symbolizes old age.

The eye with the colour white is used two times in Turkish demonstrating the conceptualization of EYE IS A CONTAINER FOR EMOTIONS. A white eye also signifies anger in Turkish as in the example of gözünü ăgartmak. Also a person with white eye is associated with evil in this language as in the idiom ak gözlü.

Despite the low frequency, saç (hair) together with sakal (beard) and saç (hair) together with baş (head) and şakak (temporal) are conceptualized by Turkish speakers in order to refer to old age. The collocation of the colour white and the body part topuk (ankle) and gerdan (throat) signifies beauty which is one of the common associations of white. What is more, the white forehead in the idiom alninin aklyla signifies pride and the mapping between white and face has generated the conceptual metonymy WHITE FOREHEAD STANDS FOR PRIDE.

On the other hand, when compared to Turkish, the number of metaphorical expressions with the colour white in which there is a body part metonymy falls 
dramatically in English. The number of these idioms is only two: white-livered and with white hands.

Liver, one of the inner body parts, is collocated with the colour white in English in order to refer to cowardice which can be regarded as culture-specific for English speaking communities.

Lastly, as observed in the idiom with white hands, morality is conceptualized through the collocation of the colour white and hand connoting honesty in English.

Table 2. Distribution of Body Part Terms in Turkish and English Black Colour Idioms

\begin{tabular}{|l|l|l|l|}
\hline Body Part Term in Turkish & Number & Body Part Term in English & Number \\
\hline Gönül/ Yürek/ Kalp (Heart) & 6 & Eye & 1 \\
\hline Göz (Eye) & 5 & Leg & 1 \\
\hline Yüz (Face) & 4 & & \\
\hline Alın (Forehead) & 2 & & \\
\hline Ağız (Mouth) & 2 & & \\
\hline Bağır (Chest) & 2 & & \\
\hline Baş (Head) & 2 & & \\
\hline Diz (Knee) & 1 & & \\
\hline Karın (Abdomen) & 1 & & \\
\hline Parmak (Finger) & 1 & & \\
\hline Kulak (Ear) & 1 & & \\
\hline Ayak (Foot) & 1 & & \\
\hline İç (Inner body) & 1 & & \\
\hline
\end{tabular}

There are 29 black colour idioms with a body part term in Turkish which are açlıktan gözü/gözleri kararmak, ăgzı kara, alnına kara sürmek, alnının kara yazısl, ayaklarına kara su inmek, dizlerine kara su inmek, gönlü kara, yüzü kara, yüzünü kara çıkarmak, gözü kara, gözü kara çıkmak, yüz karası, yürek karası, yüreği kararmak, kara yüzlü, karabaş, kara bă̆ır, gözüne kara su inmek, başına karalar bağlamak, bağrı kara, kara ağızlı, kara gönüllü, karakulak, karnı kara, on parmă̆ında on kara, gözü kararmak, gönlü kararmak, kalbi kararmak, and içi kararmak.

It is illustrated in Table 2 that kalp (heart) is the most frequently used body part in Turkish black colour idioms and it communicates emotions as observed in 
the idioms gönlü kararmak, gönlü kara, kalbi kararmak, kara gönüllü, yürek karası, and yüreği kararmak. In Turkish yürek, kalp and gönül are considered synonymous and these idioms include one of the basic human experiences which is dark and they are observed to yield EMOTION IS DARK generic level metaphor (Kövecses, 2000, p. 39). As dark is associated with the negative, all of these idiomatic expressions refer to negative emotions such as distress. Other than distress, heart is associated with ignorance as observed in kara gönüllü and malignancy in the idiom gönlü kara both of which are again negative conceptualizations.

The second most frequently used body part in Turkish black colour idioms is 'eye' as in the idioms açllktan gözü/gözleri kararmak, gözü kara, gözü kara çıkmak, gözüne kara su inmek, and gözü kararmak They all again consist of negative conceptualizations such as hunger in açlıktan gözü/gözleri kararmak, uncontrollable courage in gözü kara and gözü kara çıkmak, longing in gözüne kara su inmek and anger in gözü kararmak.

Face is another body part term which is frequently used in Turksh black colour idioms: yüzü kara, yüzünü kara çıkarmak, yüz karası, and kara yüzlü. The common point in these idioms is that they all yield BLACK FACE STANDS FOR DISGRACEFULLNESS conceptual metonymy. Thus, it can be inferred that black is associated with immorality when collocated with the face in Turkish.

When compared to Turkish body part terms constructed with the colour black, the number of body part idioms in English is very few. As illustrated in Table 2, there are only 2 body part metonymies in English one of which is constructed with 'eye' as observed in black eye connoting a malignant person. The other body part idiom is black-leg which is a culturally-specific expression originating from the fact that the bird rook has black legs and always steals food through cunningness. Even today, the term rook is used for people who deceive innocent people (Black-leg, n.d.).

When it comes to the colour red, it was observed that Turkish and English are identical in terms of the number of red colour idioms with body parts.

\section{Table 3. Distribution of Body Part Terms in Turkish and English Red Colour Idioms}

\begin{tabular}{|l|l|l|l|}
\hline Body Part Term in Turkish & Number & Body Part Term in English & Number \\
\hline Yüz (Face) & 4 & Face & 3 \\
\hline & & Hand & 1 \\
\hline
\end{tabular}

It is illustrated in Table 3 that there are 4 body part idiomatic expressions in Turkish which are yüzü al al olmak, yüz kızartıcl, yüzü kızarmak, and yüzünü klzartmak. As it is the face through which human beings can express their 
feelings and emotions, it is used in Turkish idioms mostly in order to describe shame.

In English, there are four red colour idioms with body part terms which are to catch someone red-handed, to be left red-face, red in the face, and to give someone a red face. Most of the body part relations in English red colour idioms are constructed with 'face' like Turkish. In to be left red-faced, red in the face, and give someone a red face there lies a general conceptual metonymy RED FACE STANDS FOR EMOTION, or more specifically, RED FACE STANDS FOR SHAME/ EMBARRASSMENT. This conceptual metaphor/ metonymy is embedded in Turkish and English cultures because of the physiological characteristic of the human body as the face physically becomes red when the person is embarrassed.

Table 4. Distribution of Body Part Terms in Turkish and English Yellow Colour Idioms

\begin{tabular}{|l|l|l|l|}
\hline Body Part Term in Turkish & Number & Body Part Term in English & Number \\
\hline Vein (Damar) & 1 & Belly & 1 \\
\hline & & Liver & 1 \\
\hline
\end{tabular}

In terms of the yellow colour it is illustrated in Table 4 that there is only 1 body part idiomatic expression in Turkish which is sarl damarl tutmak. In this idiom used commonly in Turkish speaking communities, there is a relationship between the target domain of obstinacy and the source domain of vein of the blond people.

In English there are 2 yellow colour idioms with body parts which are yellowbellied and yellow-livered. The common point between these two idioms is that their connotation is the emotion of fear.

Table 5. Distribution of Body Part Terms in Turkish and English Green Colour Idioms

\begin{tabular}{|l|l|l|l|}
\hline Body Part Term in Turkish & Number & Body Part Term in English & Number \\
\hline & & Eye & 1 \\
\hline & & Thumb & 1 \\
\hline & & Finger & 1 \\
\hline
\end{tabular}

Although there is no green colour idiom with body part relationship among the source and target domains n Turkish, there are 3 idioms in English which are to have green fingers and to have a green thumb, both referring to be good at gardening and the green-eyed monster attributed to the jealousy of a person among English speakers. 
Table 6. Distribution of Body Part Terms in Turkish and English Blue Colour Idioms

\begin{tabular}{|l|l|l|l|}
\hline Body Part Term in Turkish & Number & Body Part Term in English & Number \\
\hline & & Beard & 1 \\
\hline & & Eye & 1 \\
\hline & & Nose & 1 \\
\hline
\end{tabular}

As it is illustrated in Table 6, there is no idiom constructed through a body part and blue colour in Turkish. However, there are 3 idioms in English, bluenosed, a blue-eyed boy, and bluebeard, with body part metonymies. The expression bluebeard has derived from a French folktale written by Charles Perrault, referring to villain men who murder their wives and thus it requires encyclopedic background knowledge in order to grasp the meaning. The second idiom blue-nosed has originated from the Puritan settlers recognized by their blue-coloured noses because of the cold in winter (Wilkinson, 2002, p. 596), and this idiom has been embedded in the minds of the people speaking English as referring to people with pride and strict morality. Moreover, the colour blue is also collocated with 'eye' in the idiom blue-eyed boy referring to a person who is considered as favourite and well-treated especially by people of authority, hence it generates BLUE EYE STANDS FOR A FAVOURITE PERSON conceptual metonymy.

Table 7. Distribution of Body Part Terms in Turkish and English Pink Colour Idioms

\begin{tabular}{|l|l|l|l|}
\hline Body Part Term in Turkish & Number & Body Part Term in English & Number \\
\hline Yüz (Face) & 1 & & \\
\hline
\end{tabular}

As it is illustrated in Table 7 there is only 1 pink colour idiom in Turkish constructed with a body-part term which is pembe bir çehre. It refers to the healthy appearance of a person generating A PINK FACE STANDS FOR BEING HEALTY conceptual metonymy. Nevertheless, there is no body-part metonymy in English pink colour idioms.

Table 8. Distribution of Body Part Terms in Turkish and English Brown Colour Idioms

\begin{tabular}{|l|l|l|l|}
\hline Body Part Term in Turkish & Number & Body Part Term in English & Number \\
\hline & & Nose & 1 \\
\hline & & Liver & 1 \\
\hline
\end{tabular}

It can be observed from Table 8 that Turkish has no brown colour idioms with body part metonymies. However, English has 2 metonymy-based 
idioms which are brown-nose connoting to flattering someone for the sake of promotion, generating A BROWN NOSE STANDS FOR FLATTERING FOR PROMOTION conceptual metonymy, and liver-brown used to describe the physical characteristic of something.

The other three basic colour terms, orange, grey, and purple, are not collocated with body parts in the idioms used by Turkish and English speakers.

\section{Conclusion}

This study aimed to provide a systematic description of Turkish and English basic colour term idioms with body parts in terms of the cognitivist theory and demonstrate the commonalities and variations between the use of body parts in these languages revealing the embodied cognition of English and Turkish speaking communities. More specifically, it analyzed the distribution of the body part terms in English and Turkish basic colour term idioms and conceptual metonymies underlying these idioms in order to interpret the findings in terms of socio-cultural and socio-cognitive structures of English and Turkish cultures.

In terms of the frequency of the basic colour term idioms with body parts in Turkish and English, it was revealed in this study that Turkish is richer than English. It was observed that the most frequently used body part in Turkish is 'face'. The reason behind this can be the fact that face includes all the sensory organs of the body and it is the place through which the human beings can demonstrate their feelings.

However, English speakers use the basic colour terms with body parts less when compared to Turkish speakers and the number of the idioms constructed with 'liver', 'eye' and 'face' is the same.

Accordingly, the findings of the study proved that people from different speech communities use various parts of their body for conceptualizations of their daily experiences. As Synnott claims (1993) "every culture constructs its own body differently" (p. 262). People belonging to different cultures "conceptualize how the mind (i.e. the cognitive functions of thinking and feeling, etc.) is related to, or located in, the body differently" (Yu, 2009, pp. 367-368). Relatedly enough, despite the low number of commonalities, Turkish and English speaking communities differ in terms of their bodily centers because of not only linguistic but also cultural and cognitive reasons. 


\section{References:}

Aksoy Ö. A. (1998). Deyimler Sözlüğ̈̈ II. İstanbul: İnkılap Yayınları.

Barcelona, A. (2011). Reviewing the properties and prototype structure of metonymy. In R. Benczes, A. Barcelona, \& F. J. Ruiz de Mendoza Ibáñez (Eds.), Defining metonymy in cognitive linguistics: Towards a consensus view, (pp. 7-57). Amsterdam/ Philadelphia: John Benjamins Publishing Company.

Baş, M. (2015). Conceptualization of emotion through body part emotions in Turkish: A cognitive linguistic study. Unpublished PhD Thesis, Hacettepe University, Ankara.

Berlin B., P. Kay. (1969). Basic color terms: their universality and evolution. Berkeley: University of California Press.

Black-leg. (n.d.) In English Language and Usage. Retrieved from https://english. stackexchange.com/questions/353885/is-the-origin-of-the-term-blackleg-racist

Butterworth A., Gurney D., Malfroy E., G. Mark. (2002). Cambridge International Dictionary of Idioms. UK: Cambridge University Press.

Flavell L., R. Flavell. (1994). Dictionary of idioms and their origins. London: Kayle Cathie.

Gibbs, R. W. (2006). Embodiment and cognitive science. New York, NY, US: Cambridge University Press.

Hastürkoğlu, G. (2017). A cognitive study on the comparison of basic colour terms in Turkish and English idioms. Unpublished PhD Thesis, Hacettepe University, Ankara.

Kövecses, Z. (2000). Metaphor and emotion: language, culture, and body in human feeling. Cambridge: Cambridge University Press.

Lakoff G., M. Johnson. (1980). Metaphors We Live By. Chicago, London: The University of Chicago Press.

Öz, S. (2011). A corpus-based analysis of Turkish body part terms based on conceptual metaphor theory. (Unpublished Master's thesis) Retrieved from https//tez.yok.gov.tr/ UlusalTezMerkezi/

Potter E., Watson J., Lax M., Timewell M., J. Todd (eds.). (1997). Collins Cobuild Dictionary of Idioms. Harper Collins Publishers.

Radden, G. \& Kövecses, Z. (1999). Towards a theory of metonymy. In K. Panther \& G. Radden (Eds.), Metonymy in language and thought (pp. 17- 59). Amsterdam: John Benjamins.

Renton N. E. (1990). Metaphorically speaking: a dictionary of 3800 picturesque idiomatic expressions. Melbourne, New York: Warner Books.

Ruhi, Ş. \& Işık-Güler, H. (2007). Conceptualizing face and relational work in (im)politeness: revelations from politeness lexemes and idioms. Turkish. Journal of Pragmatics, 39(4), 681-711. https://doi.org/10.1016/j.pragma.2006.11.013

Siahaan, P. (2008). Did he break your heart or your liver? A contrastive study on metaphorical concepts from the source domain organ in English and in Indonesian. In F. Sharifian, R. Dirven, N. Yu, \& S. Niemeier (Eds.), Culture, body, and language: Conceptualizations of internal body organs across cultures and languages (pp. 45-74). Berlin/New York: Mouton de Gruyter.

Siefring J. (ed.). (2004). Oxford Dictionary of Idioms. New York: Oxford University Press. 
Spears R. (2005). McGraw-Hill's Dictionary of American Idioms and Phrasal Verbs. USA: McGraw-Hill.

Synnott A. (1993). The body social: symbolism, self, and society. London/New York: Routledge.

Türk Dil Kurumu. Atasözleri ve Deyimler Sözlüğ̈̈. <http://tdk.gov.tr>. [Accessed 15 Oct. 2017].

Wilkinson P.R. Thesaurus of traditional English metaphors. London: Routledge.

Yörük S., Y. Yörük. (1997). Açıklamalı Deyimler Sözlüğü. İstanbul: Serhat Yayınları.

Yu N. (2009). The Chinese heart in a cognitive perspective: culture, body and language. Berlin/NY: Mouton de Gruyter. 